\title{
Age-related Change in Relationship between White Blood Cell Count and Some Features of the Metabolic Syndrome
}

\author{
Noriyuki NAKANISHI $^{1 *}$, Kenji SUZUKI ${ }^{2}$ and Kozo TATARA ${ }^{1}$ \\ ${ }^{1}$ Department of Social and Environmental Medicine, Course of Social Medicine, Osaka University Graduate \\ School of Medicine F2, 2-2 Yamada-oka, Suita-shi, Osaka 565-0871, Japan \\ ${ }^{2}$ Japan Labor and Welfare Association, 1-24-4 Ebisu, Shibuya-ku, Tokyo 150-0013, Japan
}

Received September 25, 2003 and accepted June 12, 2004

\begin{abstract}
To examine age-related change in the strength of the association of white blood cell count (WBC) with features of the metabolic syndrome (MS), body mass index, blood pressure, total cholesterol, high-density lipoprotein (HDL) cholesterol, triglycerides, fasting plasma glucose, and uric acid were assessed as the components of the MS in 5,218 Japanese male office workers aged 2359 yr. The subjects were stratified by age into three groups of 23-39, 40-49, and 50-59 yr. WBC count showed a positive crude correlation with the components of the MS, except for HDL cholesterol (negative), in all three age groups. With an increase in age, an association between WBC count and each component of the MS declined, and an interaction with age weakened. After controlling for potential confounders, the largest differences of WBC count for each categorized feature of the MS were found among those aged 23-39 yr. Stratified analyses by smoking status and age showed that in both non-smokers and current smokers the adjusted WBC count increased as the number of features of the MS increased in all three age groups. In each category of the number of clustered features of the MS, differences of WBC count compared with the presence of no features of the MS were the largest in those aged 23-39 $\mathrm{yr}$ in both non-smokers and current smokers. The adjusted odds ratios of $\geq 3$ features of the MS also increased with an increase in WBC count in all three age groups in both non-smokers and current smokers. The adjusted odds ratios of $\geq \mathbf{3}$ features of the MS across quartiles of WBC count (lowest to highest) were the largest in the youngest age group. Our results indicate that a variety of features of the MS are associated with $\mathrm{WBC}$ count and that these tendencies are more pronounced in younger individuals in both non-smokers and current smokers.
\end{abstract}

Key words: White blood cell count, Metabolic syndrome, Risk factors, Clustering, Age, Cross-sectional study, Japanese men

\section{Introduction}

It has been repeatedly shown that white blood cells (WBCs) can participate in the pathogenesis of coronary heart disease (CHD) by an ability of the endothelium resulting in the lost of the vascular, antithrombotic and antiatherogenic properties of the vascular endothelium ${ }^{1-4}$. In addition, stimulated

*To whom correspondence should be addressed.
WBCs alter rheological properties with an increased tendency to adhere to vascular endothelium, and may result in capillary leukocytosis and subsequent increased vascular resistance ${ }^{5-7)}$. Recently, considerable interest has been focused on the relationship between inflammation and the metabolic syndrome (MS), which is characterized by insulin resistance accompanied by a cluster of risk factors for CHD (i.e. obesity, glucose metabolism disturbances, abnormal lipids, and high blood pressure $)^{8,9)}$. Because WBC counts 
are positively associated with both insulin resistance and hyperinsulinemia ${ }^{10,11}$, an increase in the WBC count could be the expression of an insulin-resistant state or involvement of the MS. Although it is still being debated whether the relation between WBC count and CHD is independent of or mediated by the presence of concomitant risk factors for CHD, recent studies have documented the WBC count as an independent risk factor for CHD even when potential confounders are taken into account ${ }^{12,13)}$.

As for the effect of age in the association with CHD risk factors, it has been demonstrated that the relative risk for cardiovascular disease associated with CHD risk factors such as obesity, hypertension, and dyslipidemia declines with age $^{14-18)}$. Since atherosclerotic lesions appear at an early age $^{19,20)}$, detection and control of CHD risk factors are important to prevent the development of CHD in individuals, even while young. Several studies ${ }^{10,21-25)}$ have shown that clustered features of the MS is associated with the appearance of an increment in the number of WBC count. However, it has not been clarified whether the associations between WBC count and features of the MS changes with age. The aim of the present study was to examine whether there are any differences in the strength of the association of WBC count with some features of the MS by age in a large populationbased sample.

\section{Materials and Methods}

A survey to evaluate the association between WBC count and different components of the MS was conducted in May 1996 at one of the biggest building contractors in Japan. The Industrial Safety and Health Law in Japan requires the employer to conduct annual health examinations of all employees, and employees are required by law to participate. A signed self-administered questionnaire is a part of this examination, and the employee data, which are anonymous, are available for research with the approval of the employer. All Japanese male office workers aged 23-59 yr in May 1996 were invited to take a survey $(n=5,280)$, and the participation rate was $99.6 \%(\mathrm{n}=5,275)$. Of the 5,275 participants, 57 men who had a past history of either CHD or stroke were excluded. The remaining 5,218 men constituted the study population, and no one answered yes to a question about illness with fever on the day of the examination.

The survey included medical history, a questionnaire on alcohol intake and smoking, physical examination, anthropometric measurements, blood pressure measurement, and collection of blood samples for laboratory analysis. The participants were asked to fast for at least 8 $\mathrm{h}$ and to avoid heavy physical activity for more than $2 \mathrm{~h}$ before the examinations. Medical history and use of prescription drugs were assessed by the examining physicians. Data on alcohol intake and smoking habits were obtained by interview. The questions about alcohol intake included items about the frequency of alcohol consumption per week, the type of alcoholic beverage, and the usual amount consumed daily in units of "go" (a traditional Japanese unit of measurement, by volume, corresponding to $23 \mathrm{~g}$ of ethanol). Weekly alcohol intake was calculated and then converted to daily alcohol consumption by using standard Japanese tables. The questionnaire also asked about smoking habits (never, past, or current smoker); past or current smokers were asked about the number of cigarettes smoked per day and the duration of smoking in years. In this study, past and never smokers were combined, and the current amount of cigarettes smoked was used in the analysis. Body mass index (BMI, $\mathrm{kg} / \mathrm{m}^{2}$ ) was used as a measure of overall obesity. Blood pressures were measured by trained observers using standard mercury sphygmomanometers on the right arm of seated participants who had rested for $5 \mathrm{~min}$. After the measurement of the blood pressure and while the participant was fasting, blood samples were drawn from an antecubital vein. WBC counts were determined by using a Sysmex E-4000 autoanalyzer (Toa Medical Electronics Co, Ltd., Tokyo, Japan). Serum total cholesterol, high-density lipoprotein (HDL) cholesterol, triglycerides, and uric acid and fasting plasma glucose were measured with Olympus AU-5200 equipment (Olympus Japan Co, Ltd., Tokyo, Japan) at FALCO Biosystems Tokyo Ltd. (Tokyo, Japan).

Characteristics of the MS were defined as follows ${ }^{26-29)}$ : obesity, BMI $\geq 25 \mathrm{~kg} / \mathrm{m}^{2}$; hypertension, systolic blood pressure (SBP) $\geq 140 \mathrm{mmHg}$ and/or diastolic blood pressure (DBP) $\geq 90 \mathrm{mmHg}$ and/or medication for hypertension; hypercholesterolemia, total cholesterol level $\geq 5.69 \mathrm{mmol} / \mathrm{l}$ and/or medication for dyslipidemia; low HDL cholesterol, HDL cholesterol level $<1.03 \mathrm{mmol} / \mathrm{l}$; hypertriglyceridemia, triglyceride level $\geq 1.69 \mathrm{mmol} / \mathrm{l}$ and/or medication for dyslipidemia; high fasting plasma glucose, fasting plasma glucose level $\geq 6.1 \mathrm{mmol} / \mathrm{l}$ and/or medication for diabetes; and hyperuricemia, uric acid level $\geq 446 \mu \mathrm{mol} / \mathrm{l}$ and/or medication for hyperuricemia.

\section{Statistical Analysis}

One-way analysis of variance and the chi-square test were used to analyze the statistical differences among 
Table 1. Characteristics of 5,218 Japanese male office workers who participated in the study, according to age*

\begin{tabular}{|c|c|c|c|c|c|}
\hline \multirow[b]{2}{*}{ Characteristic } & \multicolumn{4}{|c|}{ Age (yr) } & \multirow[b]{2}{*}{$P$ value } \\
\hline & $\begin{array}{c}23-39 \\
(n=1,865)\end{array}$ & $\begin{array}{c}40-49 \\
(n=1,894)\end{array}$ & $\begin{array}{c}50-59 \\
(n=1,459)\end{array}$ & $\begin{array}{c}\text { Total } \\
(n=5,218)\end{array}$ & \\
\hline White blood cell count $\left(10^{9}\right.$ cells $\left./ \mathrm{l}\right)$ & $6.24 \pm 1.63$ & $6.77 \pm 1.89$ & $6.67 \pm 1.76$ & $6.55 \pm 1.78$ & $<0.001$ \\
\hline Body mass index $\left(\mathrm{kg} / \mathrm{m}^{2}\right)$ & $23.0 \pm 2.8$ & $23.7 \pm 2.8$ & $23.6 \pm 2.7$ & $23.4 \pm 2.8$ & $<0.001$ \\
\hline Alcohol consumption (g/day of ethanol) & $16.1 \pm 16.1$ & $25.1 \pm 20.3$ & $25.4 \pm 20.7$ & $22.0 \pm 19.5$ & $<0.001$ \\
\hline Current drinkers $(\%)$ & 81.7 & 85.3 & 83.3 & 83.5 & 0.010 \\
\hline Cigarette smoking (cigarettes/day) & $10.0 \pm 13.2$ & $15.1 \pm 16.5$ & $14.1 \pm 15.9$ & $13.0 \pm 15.4$ & $<0.001$ \\
\hline Ex-smokers (\%) & 11.3 & 18.8 & 23.3 & 17.4 & $<0.001$ \\
\hline Current smokers (\%) & 43.6 & 52.4 & 51.1 & 48.9 & $<0.001$ \\
\hline Systolic blood pressure $(\mathrm{mmHg})$ & $121.6 \pm 12.6$ & $128.6 \pm 14.6$ & $132.0 \pm 15.5$ & $127.1 \pm 14.8$ & $<0.001$ \\
\hline Diastolic blood pressure $(\mathrm{mmHg})$ & $71.4 \pm 10.7$ & $79.8 \pm 11.4$ & $81.4 \pm 11.1$ & $77.3 \pm 11.9$ & $<0.001$ \\
\hline Total cholesterol (mmol/l) & $4.67 \pm 0.79$ & $5.14 \pm 0.83$ & $5.16 \pm 0.79$ & $4.98 \pm 0.84$ & $<0.001$ \\
\hline High-density lipoprotein cholesterol ( $\mathrm{mmol} / \mathrm{l})$ & $1.44 \pm 0.32$ & $1.43 \pm 0.34$ & $1.45 \pm 0.37$ & $1.44 \pm 0.34$ & 0.285 \\
\hline Triglyceride $(\mathrm{mmol} / \mathrm{l})$ & $1.02 \pm 0.88$ & $1.37 \pm 1.04$ & $1.35 \pm 0.96$ & $1.24 \pm 0.98$ & $<0.001$ \\
\hline Fasting plasma glucose $(\mathrm{mmol} / \mathrm{l})$ & $4.72 \pm 0.43$ & $5.08 \pm 1.00$ & $5.24 \pm 1.03$ & $5.00 \pm 0.88$ & $<0.001$ \\
\hline Uric acid $(\mu \mathrm{mol} / \mathrm{l})$ & $341.6 \pm 69.4$ & $346.0 \pm 74.2$ & $341.2 \pm 75.5$ & $343.1 \pm 72.9$ & 0.090 \\
\hline \multicolumn{6}{|l|}{ Medical treatment $(\%)$} \\
\hline Hypertension & 0.4 & 5.5 & 11.4 & 5.3 & $<0.001$ \\
\hline Lipidemia & 0.3 & 2.4 & 3.2 & 1.9 & $<0.001$ \\
\hline Diabetes & 0.2 & 1.8 & 4.1 & 1.9 & $<0.001$ \\
\hline Hyperuriccemia & 0.3 & 1.1 & 3.3 & 1.4 & $<0.001$ \\
\hline Others & 2.0 & 4.5 & 4.6 & 3.6 & $<0.001$ \\
\hline
\end{tabular}

*: Unless otherwise indicated, values are expressed as mean \pm standard deviation.

characteristics of participants according to age. Categories of age were defined by the following three groups: 23-39, 40-49, and 50-59 yr. Spearman's rank correlation analyses were performed between values for WBC count and components of the MS. The interaction between age and each component of the MS was also tested by introducing product terms to models with the original variables. Differences of WBC count were calculated across categorized features of the MS by means of a multiple linear regression model. Except for obesity, differences of WBC count were adjusted for age (yr), cigarette smoking (cigarettes/d), alcohol consumption ( $\mathrm{g} / \mathrm{d}$ of ethanol), medical treatment (no or yes), and the remaining components of the MS (BMI $\left[\mathrm{kg} / \mathrm{m}^{2}\right]$, systolic BP [mmHg], total cholesterol [mmol/l], HDL cholesterol $[\mathrm{mmol} / \mathrm{l}]$, triglycerides $[\mathrm{mmol} / \mathrm{l}]$, fasting plasma glucose $[\mathrm{mmol} / \mathrm{l}]$, and uric acid $[\mu \mathrm{mol} / \mathrm{l}])$. As for obesity, differences of WBC count were adjusted for age, cigarette smoking, alcohol consumption, and medical treatment, because the other components of the MS are outcomes of obesity rather than confounders. Subjects with a different number of components of the MS were grouped into five subgroups (graded from 0 through $\geq 4$ ). Differences of WBC count compared with the presence of no features of the MS were calculated by creating four dummy variables and were adjusted for age, smoking, alcohol consumption, and medical treatment by means of a multiple linear regression model. Logistic regression analyses were also used to evaluate the multivariate relations between WBC count and the risk of $\geq 3$ features of the MS. WBC count was divided into quartiles $\left(<53,53-62,63-73\right.$, and $\geq 7410^{9}$ cells/l), and the linear trends in risks were evaluated by using the median value for each category of WBC count.

Data were analyzed by using the SPSS/PC statistical package (SPSS Inc., Chicago, Ill., USA). All reported P values are two-tailed; those less than 0.05 were considered statistically significant.

\section{Results}

Table 1 shows the characteristics of the study sample, stratified by age into three groups of $23-39,40-49$, and 50 59 yr. The mean WBC count, BMI, alcohol consumption, cigarette smoked per day, SBP, DBP, total cholesterol level, triglyceride level, and fasting plasma glucose level and the percentages of participants who were current drinkers and ex- and current smokers and were taking medication for hypertension, dyslipidemia, diabetes, hyperuricemia, and other diseases differed significantly by age. Individuals aged 
Table 2. Spearman's rank correlations of white blood cell count with age and selected variables of the metabolic syndrome, according to age

\begin{tabular}{|c|c|c|c|c|c|c|}
\hline \multirow{4}{*}{ Variable } & \multicolumn{6}{|c|}{ Age (yr) } \\
\hline & \multicolumn{2}{|c|}{$23-39$} & \multicolumn{2}{|c|}{$40-49$} & \multicolumn{2}{|c|}{$50-59$} \\
\hline & \multicolumn{2}{|c|}{$n=1,865$} & \multicolumn{2}{|c|}{$n=1,894$} & \multicolumn{2}{|c|}{$n=1,459$} \\
\hline & $r$ & $P$ value & $r$ & $\mathrm{P}$ value & $r$ & $P$ value \\
\hline Age $(y r)$ & 0.101 & $<0.001$ & 0.014 & 0.529 & 0.010 & 0.703 \\
\hline Body mass index $\left(\mathrm{kg} / \mathrm{m}^{2}\right)$ & 0.218 & $<0.001$ & 0.122 & $<0.001$ & 0.038 & 0.142 \\
\hline Systolic blood pressure $(\mathrm{mmHg})$ & 0.188 & $<0.001$ & 0.092 & $<0.001$ & 0.067 & 0.011 \\
\hline Diastolic blood pressure $(\mathrm{mmHg})$ & 0.131 & $<0.001$ & 0.031 & 0.177 & 0.035 & 0.180 \\
\hline Total cholesterol (mmol/l) & 0.120 & $<0.001$ & 0.057 & 0.013 & 0.003 & 0.895 \\
\hline High-density lipoprotein cholesterol ( $\mathrm{mmol} / \mathrm{l})$ & -0.209 & $<0.001$ & -0.183 & $<0.001$ & -0.174 & $<0.001$ \\
\hline Triglyceride (mmol/l) & 0.248 & $<0.001$ & 0.202 & $<0.001$ & 0.187 & $<0.001$ \\
\hline Fasting plasma glucose (mmol/l) & 0.119 & $<0.001$ & 0.092 & $<0.001$ & 0.101 & $<0.001$ \\
\hline Uric acid $(\mu \mathrm{mol} / \mathrm{l})$ & 0.099 & $<0.001$ & 0.019 & 0.409 & 0.004 & 0.889 \\
\hline \multicolumn{7}{|c|}{ Interaction between age (years) and each of the selected variables* } \\
\hline Body mass index $\left(\mathrm{kg} / \mathrm{m}^{2}\right)$ & 0.207 & $<0.001$ & 0.122 & $<0.001$ & 0.036 & 0.166 \\
\hline Systolic blood pressure (mmHg) & 0.176 & $<0.001$ & 0.086 & $<0.001$ & 0.073 & 0.005 \\
\hline Diastolic blood pressure $(\mathrm{mmHg})$ & 0.143 & $<0.001$ & 0.031 & 0.171 & 0.034 & 0.196 \\
\hline Total cholesterol $(\mathrm{mmol} / \mathrm{l})$ & 0.142 & $<0.001$ & 0.064 & 0.006 & 0.003 & 0.906 \\
\hline High-density lipoprotein cholesterol (mmol/l) & -0.187 & $<0.001$ & -0.176 & $<0.001$ & -0.168 & $<0.001$ \\
\hline Triglyceride (mmol/l) & 0.250 & $<0.001$ & 0.201 & $<0.001$ & 0.186 & $<0.001$ \\
\hline Fasting plasma glucose (mmol/l) & 0.136 & $<0.001$ & 0.080 & $<0.001$ & 0.091 & $<0.001$ \\
\hline Uric acid $(\mu \mathrm{mol} / \mathrm{l})$ & 0.135 & $<0.001$ & 0.018 & 0.425 & 0.005 & 0.838 \\
\hline
\end{tabular}

*: Interactions were tested by introducing product terms to models with original variables.

23-39 yr had the lower levels of WBC count, BMI, alcohol consumption, cigarettes smoked per day, total cholesterol, and triglyceride. The mean SBP, DBP and fasting plasma glucose level and the percentages of those who were taking medication for hypertension, dyslipidemia, diabetes, hyperuricemia, and other diseases increased with an increase in age. On the other hand, HDL cholesterol level and uric acid level did not differ significantly among three groups.

Table 2 shows Spearman's rank correlation coefficients of WBC count with age and selected variables of the MS according to age. There were statistically significant unadjusted correlations between WBC count and SBP, HDL cholesterol level (negative), triglyceride level, and fasting plasma glucose level in all three age groups. BMI and total cholesterol level were significantly associated with WBC count among those aged 23-39 and 40-49 yr. Age, DBP, and uric acid level were significantly associated with WBC count only among those aged 23-39 yr. The largest correlation coefficients between WBC count and each variable of the MS were observed among those aged 23-39 yr. As for the interaction between age and each component of the MS, the interactions with age weakened with an increase in age in all the components of the MS.

Table 3 shows the means and differences of WBC count for cigarette smoking, alcohol intake, and medical treatment. In each age group of 23-39, 40-49, and 50-59 yr, the mean WBC count was significantly higher in current smokers than in never smokers, but did not differ significantly between ex-smokers and never smokers. As for alcohol intake, the mean WBC count was significantly lower in current drinkers than in non-drinkers in the age groups of 40-49 and 50-59 $\mathrm{yr}$, but did not differ significantly in the age group of 23-39 yr. The mean WBC count was higher in those with medical treatment than in those without in each age group, and differed significantly in the age groups of 40-49 and 50-59 yr.

Table 4 shows the adjusted means and differences of WBC count for categorized components of the MS by age. After controlling for potential confounders for each component of the MS, the adjusted means of WBC count were significantly higher in subjects with obesity, hypertension, hypercholesterolemia, and hypertriglyceridemia among those aged 23-39 yr. For individuals aged 40-49 yr, the adjusted means of WBC count were significantly higher in those with obesity and hypertension. For individuals aged 50-59 yr, the adjusted means of WBC count were significantly higher in those with hypertension and high fasting plasma glucose level. The largest differences of WBC count for each categorized feature of the MS were observed among those 
Table 3. Means and differences of white blood cell count $\left(10^{9}\right.$ cells/l) for cigarette smoking, alcohol intake, and medical treatment, according to age

\begin{tabular}{|c|c|c|c|c|c|c|c|c|c|c|c|c|}
\hline \multirow{4}{*}{ Item } & \multicolumn{12}{|c|}{ Age (years) } \\
\hline & \multicolumn{4}{|c|}{$23-39$} & \multicolumn{4}{|c|}{$40-49$} & \multicolumn{4}{|c|}{$50-59$} \\
\hline & \multirow[b]{2}{*}{$n$} & \multicolumn{3}{|c|}{ Difference } & \multicolumn{4}{|c|}{ Difference } & \multirow[b]{2}{*}{$n$} & \multicolumn{3}{|c|}{ Difference } \\
\hline & & Mean & $\begin{array}{l}\text { (95\% confidence } \\
\text { interval) }\end{array}$ & $P$ value & $n$ & Mean & $\begin{array}{l}\text { (95\% confidence } \\
\text { interval) }\end{array}$ & P value & & Mean & $\begin{array}{c}\text { (95\% confidence } \\
\text { interval) }\end{array}$ & $P$ value \\
\hline \multicolumn{13}{|c|}{ Cigarette smoking } \\
\hline Never & 842 & 5.79 & - & & 545 & 5.95 & - & & 373 & 5.86 & - & \\
\hline Past & 210 & 5.87 & $0.08(-0.15,0.32)$ & 0.495 & 357 & 6.00 & $0.04(-0.19,0.27)$ & 0.721 & 340 & 6.03 & $0.17(-0.07,0.41)$ & 0.158 \\
\hline Current & 813 & 6.81 & $1.02(0.87,1.17)$ & $<0.001$ & 992 & 7.49 & $1.54(1.36,1.72)$ & $<0.001$ & 746 & 7.36 & $1.50(1.30,1.70)$ & $<0.001$ \\
\hline \multicolumn{13}{|c|}{ Current alcohol intake } \\
\hline No & 342 & 6.26 & - & & 278 & 7.06 & - & & 243 & 7.01 & - & \\
\hline Yes & 1,523 & 6.24 & $-0.03(-0.22,0.16)$ & 0.781 & 1,616 & 6.72 & $-0.34(-0.58,-0.10)$ & 0.005 & 1,216 & 6.60 & $-0.42(-0.66,-0.18)$ & 0.001 \\
\hline \multicolumn{13}{|c|}{ Medical treatment } \\
\hline No & 1,807 & 6.24 & - & & 1,630 & 6.71 & - & & 1,123 & 6.62 & - & \\
\hline Yes & 58 & 6.36 & $0.12(-0.28,0.51)$ & 0.562 & 264 & 7.08 & $0.37(0.14,0.59)$ & 0.001 & 336 & 6.82 & $0.20(0.01,0.40)$ & 0.039 \\
\hline
\end{tabular}

Table 4. Adjusted means and differences of white blood cell count $\left(10^{9}\right.$ cells/l) for categorized features of the metabolic syndrome, according to age

\begin{tabular}{|c|c|c|c|c|c|c|c|c|c|c|c|c|}
\hline \multirow{4}{*}{ Item* } & \multicolumn{12}{|c|}{ Age (yr) } \\
\hline & \multicolumn{4}{|c|}{$23-39$} & \multicolumn{4}{|c|}{$40-49$} & \multicolumn{4}{|c|}{$50-59$} \\
\hline & \multirow[b]{2}{*}{$n$} & \multicolumn{3}{|c|}{ Difference } & \multicolumn{4}{|c|}{ Difference } & \multirow[b]{2}{*}{$n$} & \multicolumn{3}{|c|}{ Difference } \\
\hline & & Mean & $\begin{array}{l}\text { (95\% confidence } \\
\text { interval) }\end{array}$ & $P$ value & $n$ & Mean & $\begin{array}{c}\text { (95\% confidence } \\
\text { interval) }\end{array}$ & P value & & Mean & $\begin{array}{l}\text { (95\% confidence } \\
\text { interval) }\end{array}$ & $P$ value \\
\hline \multicolumn{13}{|c|}{ Obesity $^{\dagger}$} \\
\hline No & 1,465 & 6.13 & - & & 1,344 & 6.64 & - & & 1,048 & 6.66 & - & \\
\hline Yes & 400 & 6.65 & $0.51(0.35,0.68)$ & $<0.001$ & 550 & 7.07 & $0.42(0.26,0.59)$ & $<0.001$ & 411 & 6.69 & $0.03(-0.15,0.21)$ & 0.720 \\
\hline \multicolumn{13}{|c|}{ Hypertension ${ }^{\ddagger}$} \\
\hline No & 1,682 & 6.19 & - & & 1,347 & 6.70 & - & & 910 & 6.54 & - & \\
\hline Yes & 183 & 6.71 & $0.52(0.28,0.75)$ & $<0.001$ & 547 & 6.93 & $0.24(0.06,0.41)$ & 0.009 & 549 & 6.8 & $0.34(0.16,0.52)$ & $<0.001$ \\
\hline \multicolumn{13}{|c|}{ Hypercholesterolemia } \\
\hline No & 1,664 & 6.21 & - & & 1,392 & 6.72 & - & & 1,085 & 6.69 & - & \\
\hline Yes & 201 & 6.54 & $0.33(0.11,0.56)$ & 0.004 & 502 & 6.89 & $0.17(-0.03,0.37)$ & 0.097 & 374 & 6.60 & $-0.09(-0.28,0.11)$ & 0.378 \\
\hline \multicolumn{13}{|c|}{ Low high-density lipoprotein cholesterol level } \\
\hline No & 1,723 & 6.22 & - & & 1,703 & 6.76 & - & & 1,307 & 6.65 & - & \\
\hline Yes & 142 & 6.48 & $0.25(-0.02,0.53)$ & 0.066 & 191 & 6.80 & $0.04(-0.24,0.32)$ & 0.762 & 152 & 6.83 & $0.19(-0.11,0.48)$ & 0.211 \\
\hline \multicolumn{13}{|c|}{ Hypertriglyceridemia } \\
\hline No & 1,667 & 6.22 & - & & 1,443 & 6.72 & - & & 1,113 & 6.64 & - & \\
\hline Yes & 198 & 6.47 & $0.25(0.01,0.49)$ & 0.039 & 451 & 6.91 & $0.19(-0.01,0.39)$ & 0.058 & 346 & 6.74 & $0.09(-0.12,0.31)$ & 0.390 \\
\hline \multicolumn{13}{|c|}{ High fasting plasma glucose level ${ }^{\ddagger}$} \\
\hline No & 1,847 & 6.24 & - & & 1,777 & 6.76 & - & & 1,306 & 6.63 & - & \\
\hline Yes & 18 & 6.82 & $0.58(-0.11,1.28)$ & 0.101 & 117 & 6.75 & $-0.02(-0.34,0.31)$ & 0.928 & 153 & 6.94 & $0.31(0.03,0.58)$ & 0.028 \\
\hline \multicolumn{13}{|c|}{ Hyperuricemia ${ }^{\ddagger}$} \\
\hline No & 1,711 & 6.23 & - & & 1,726 & 6.76 & - & & 1,297 & 6.66 & - & \\
\hline Yes & 154 & 6.34 & $0.10(-0.15,0.35)$ & 0.419 & 168 & 6.80 & $0.04(-0.24,0.31)$ & 0.790 & 162 & 6.72 & $0.06(-0.20,0.33)$ & 0.644 \\
\hline
\end{tabular}

*: Obesity, body mass index $\geq 25.0 \mathrm{~kg} / \mathrm{m}^{2}$; hypertension, systolic blood pressure $\geq 140 \mathrm{mmHg}$ and/or diastolic blood pressure $\geq 90 \mathrm{mmHg}$ and/or medication for hypertension; hypercholesterolemia, total cholesterol level $\geq 5.69 \mathrm{mmol} / \mathrm{l}$ and/or medication for dyslipidemia; low high-density lipoprotein cholesterol level, high-density lipoprotein cholesterol level $<1.03 \mathrm{mmol} / \mathrm{l}$; hypertriglyceridemia, triglycerides $\geq 1.69 \mathrm{mmol} / 1$ and/or medication for dyslipidemia; high fasting plasma glucose level, fasting plasma glucose level $\geq 6.1 \mathrm{mmol} / \mathrm{l}$ and/or medication for diabetes; hyperuricemia, uric acid $\geq 446 \mu \mathrm{mol} / \mathrm{l}$ and/

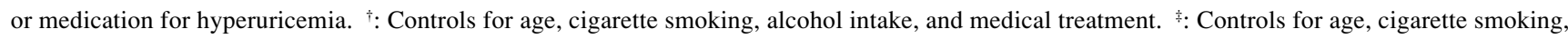
alcohol intake, medical treatment, and all other components of the metabolic syndrome. 
Table 5. Adjusted means and differences of white blood cell count $\left(10^{9}\right.$ cells/l) for clustered features of the metabolic syndrome, according to smoking status and age

\begin{tabular}{|c|c|c|c|c|c|c|c|c|c|c|c|c|}
\hline \multirow{4}{*}{$\begin{array}{c}\text { Smoiking status } \\
\text { Number of } \\
\text { features }\end{array}$} & \multicolumn{12}{|c|}{ Age (yr) } \\
\hline & \multicolumn{4}{|c|}{$23-39$} & \multicolumn{4}{|c|}{$40-49$} & \multicolumn{4}{|c|}{$50-59$} \\
\hline & \multirow[b]{2}{*}{$n$} & \multicolumn{3}{|c|}{ Difference } & \multirow[b]{2}{*}{$n$} & \multicolumn{3}{|c|}{ Difference } & \multirow[b]{2}{*}{$n$} & \multirow{2}{*}{\multicolumn{2}{|c|}{$\begin{array}{cc} & \text { Difference } \\
\text { Mean } & \text { (95\% confidence } \\
& \text { interval) }\end{array}$}} & \multirow[b]{2}{*}{$\mathrm{P}$ value } \\
\hline & & Mean & $\begin{array}{l}\text { (95\% confidence } \\
\text { interval) }\end{array}$ & P value & & Mean & $\begin{array}{c}\text { (95\% confidence } \\
\text { interval) }\end{array}$ & P value & & & & \\
\hline \multicolumn{13}{|l|}{ Non-smokers* } \\
\hline 0 & 643 & 5.57 & - & & 275 & 5.71 & - & & 180 & 5.67 & - & \\
\hline 1 & 249 & 6.01 & $0.44(0.25,0.63)$ & 0.002 & 279 & 5.83 & $0.12(-0.11,0.35)$ & 0.324 & 224 & 5.87 & $0.20(-0.04,0.44)$ & 0.105 \\
\hline 2 & 111 & 6.32 & $0.75(0.48,1.01)$ & $<0.001$ & 194 & 6.18 & $0.47(0.21,0.73)$ & $<0.001$ & 151 & 6.08 & $0.40(0.13,0.68)$ & 0.004 \\
\hline 3 & 32 & 6.43 & $0.86(0.40,1.33)$ & $<0.001$ & 82 & 6.19 & $0.48(0.13,0.83)$ & 0.007 & 97 & 6.14 & $0.47(0.16,0.78)$ & 0.003 \\
\hline$\geq 4$ & 17 & 7.19 & $1.62(0.98,2.27)$ & $<0.001$ & 72 & 6.68 & $0.97(0.60,1.34)$ & $<0.001$ & 61 & 6.33 & $0.65(0.29,1.02)$ & 0.001 \\
\hline $\mathrm{P}$ value for trend & & & & $<0.001$ & & & & $<0.001$ & & & & $<0.001$ \\
\hline \multicolumn{13}{|l|}{ Current smokers ${ }^{\dagger}$} \\
\hline 0 & 432 & 6.51 & - & & 342 & 7.21 & - & & 205 & 7.35 & - & \\
\hline 1 & 209 & 7.00 & $0.48(0.20,0.76)$ & 0.001 & 270 & 7.45 & $0.24(-0.07,0.55)$ & 0.127 & 240 & 7.18 & $-0.18(-0.52,0.17)$ & 0.316 \\
\hline 2 & 103 & 7.14 & $0.63(0.26,1.00)$ & 0.001 & 198 & 7.51 & $0.30(-0.04,0.64)$ & 0.084 & 147 & 7.50 & $0.15(-0.25,0.54)$ & 0.460 \\
\hline 3 & 46 & 7.50 & $0.98(0.47,1.50)$ & $<0.001$ & 108 & 7.89 & $0.68(0.26,1.11)$ & 0.002 & 94 & 7.40 & $0.04(-0.41,0.50)$ & 0.848 \\
\hline$\geq 4$ & 23 & 7.82 & $1.31(0.60,2.02)$ & $<0.001$ & 74 & 8.30 & $1.09(0.60,1.58)$ & $<0.001$ & 60 & 7.68 & $0.32(-0.22,0.86)$ & 0.242 \\
\hline $\mathrm{P}$ value for trend & & & & $<0.001$ & & & & $<0.001$ & & & & 0.165 \\
\hline
\end{tabular}

*: Controls for age, alcohol intake, and medical treatment. ${ }^{\dagger}$ : Additional control for cigarette smoking.

aged 23-39 yr.

Table 5 shows the adjusted means and differences of WBC count for clustered components of the MS by smoking status and age. Never smokers and ex-smokes were combined as non-smokers, because the mean WBC count did not differ significantly between never smokers and ex-smokers. For non-smokers aged 23-39 yr, the adjusted differences of WBC count in those with the presence of $1,2,3$, and $\geq 4$ features of the MS, compared with those without features of the MS, were $0.44,0.75,0.86$, and $1.6210^{9}$ cells/l, respectively, with a statistically highly significant trend ( $\mathrm{P}$ for trend $<0.001$ ). The respective differences of WBC count compared with non-smokers without features of the MS were 0.12, 0.47, 0.48 , and $0.9710^{9}$ cells/l for those aged $40-49 \mathrm{yr}$ and 0.20 , $0.40,0.47$, and $0.6510^{9}$ cells/l for those aged 50-59 $\mathrm{yr}(\mathrm{P}$ for trend $<0.001$ for both). For current smokers aged 23$39 \mathrm{yr}$, the adjusted differences of WBC count in those with the presence of $1,2,3$, and $\geq 4$ features of the MS, compared with those without features of the MS, were $0.48,0.63,0.98$, and $1.3110^{9}$ cells/l, respectively ( $\mathrm{P}$ for trend $<0.001$ ). The respective differences of WBC count compared with current smokers without features of the MS were $0.24,0.30,0.68$, and $1.0910^{9} \mathrm{cells} / \mathrm{l}$ for those aged $40-49 \mathrm{yr}$ and $-0.18,0.15$, 0.04 , and $0.3210^{9}$ cells/l for those aged 50-59 yr (P for trend $<0.001$ and $=0.165$, respectively). In each category of the number of clustered features of the MS, differences of WBC count compared with the presence of no features of the MS were the largest in those aged 23-39 $\mathrm{yr}$ in both non-smokers and current smokers.

Table 6 shows the distribution of number of features of the MS and adjusted odds ratios of $\geq 3$ features of the MS across quartiles of WBC count by smoking status and age. For non-smokers, the percentage of those with the increased number of features of the MS increased with an increase in WBC count in each age group of 23-39, 40-49, and 50-59 $\mathrm{yr}$ ( $\mathrm{P}$ for trend $<0.001$ for all). Among non-smokers aged 23-39 yr, the adjusted odds ratio of $\geq 3$ features of the MS compared with WBC count of $<5310^{9}$ cells/l was $1.36,4.05$, and 4.92 for WBC count of 53-62, 63-73, and $\geq 7410^{9}$ cells/ 1 , respectively ( $\mathrm{P}$ for trend $<0.001$ ). The respective adjusted odds ratios of $\geq 3$ features of the MS compared with WBC count of $<5310^{9}$ cells/l were 1.92, 2.16, and 3.34 for those aged $40-49 \mathrm{yr}$ and $2.63,3.05$, and 2.54 for those aged 50-59 $\mathrm{yr}$ (P for trend $<0.001$ for both). For current smokers, the percentage of those with the increased number of features of the MS also increased with an increase in WBC count in each age group of 23-39, 40-49, and 50-59 yr ( $\mathrm{P}$ for trend $<0.001$, $<0.001$, and $=0.015$, respectively). Among current smokers aged 23-39 yr, the adjusted odds ratio of $\geq 3$ features of the MS compared with WBC count of $<5310^{9}$ cells/l was 2.99 , 7.62, and 8.94 for WBC count of 53-62, 63-73, and $\geq 7410^{9}$ cells/1, respectively ( $\mathrm{P}$ for trend $<0.001$ ). The respective 
Table 6. Distribution of number of features of the metabolic syndrome and adjusted odds ratios* of $\geq \mathbf{3}$ features of the metabolic syndrome across quartiles of white blood cell count, according to smoking status and age

\begin{tabular}{|c|c|c|c|c|c|c|c|}
\hline \multirow{2}{*}{$\begin{array}{c}\text { Smoking } \\
\text { status }\end{array}$} & \multirow{2}{*}{$\begin{array}{l}\text { Age } \\
(\mathrm{yr})\end{array}$} & \multirow{2}{*}{$\begin{array}{c}\text { Number } \\
\text { of features }\end{array}$} & \multicolumn{4}{|c|}{ White blood cell count $\left(10^{9}\right.$ cells $\left./ \mathrm{l}\right)$} & \multirow{2}{*}{$\begin{array}{l}\text { P value } \\
\text { for trend }\end{array}$} \\
\hline & & & $<53$ & $53-62$ & $63-73$ & $\geq 74$ & \\
\hline \multirow[t]{21}{*}{ Non-smokers ${ }^{\dagger}$} & \multirow[t]{7}{*}{ 23-39 } & $n$ & 386 & 338 & 216 & 112 & \\
\hline & & 0 & $72.3 \%$ & $61.5 \%$ & $51.4 \%$ & $40.2 \%$ & \\
\hline & & 1 & $18.7 \%$ & $26.0 \%$ & $25.5 \%$ & $30.4 \%$ & \\
\hline & & 2 & $6.7 \%$ & $9.2 \%$ & $15.3 \%$ & $18.8 \%$ & \\
\hline & & 3 & $2.1 \%$ & $2.7 \%$ & $4.2 \%$ & $5.4 \%$ & \\
\hline & & $\geq 4$ & $0.3 \%$ & $0.6 \%$ & $3.7 \%$ & $5.4 \%$ & \\
\hline & & $\geq 3$ & $1.0(-)$ & $1.36(0.54,3.43)$ & $4.05(1.70,9.67)$ & $4.92(1.92,12.63)$ & $<0.001$ \\
\hline & \multirow[t]{7}{*}{$40-49$} & $n$ & 296 & 272 & 208 & 126 & \\
\hline & & 0 & $40.5 \%$ & $28.7 \%$ & $22.6 \%$ & $23.8 \%$ & \\
\hline & & 1 & $32.8 \%$ & $32.0 \%$ & $29.8 \%$ & $26.2 \%$ & \\
\hline & & 2 & $16.9 \%$ & $21.3 \%$ & $27.4 \%$ & $23.0 \%$ & \\
\hline & & 3 & $5.7 \%$ & $11.0 \%$ & $11.1 \%$ & $9.5 \%$ & \\
\hline & & $\geq 4$ & $4.1 \%$ & $7.0 \%$ & $9.1 \%$ & $17.5 \%$ & \\
\hline & & $\geq 3$ & $1.0(-)$ & $1.92(1.16,3.18)$ & $2.16(1.27,3.69)$ & $3.34(1.88,5.93)$ & $<0.001$ \\
\hline & \multirow[t]{7}{*}{$50-59$} & $n$ & 217 & 237 & 168 & 91 & \\
\hline & & 0 & $33.2 \%$ & $24.5 \%$ & $22.6 \%$ & $13.2 \%$ & \\
\hline & & 1 & $35.9 \%$ & $31.6 \%$ & $25.0 \%$ & $31.9 \%$ & \\
\hline & & 2 & $19.8 \%$ & $18.6 \%$ & $22.6 \%$ & $28.6 \%$ & \\
\hline & & 3 & $8.8 \%$ & $13.9 \%$ & $17.9 \%$ & $16.5 \%$ & \\
\hline & & $\geq 4$ & $2.3 \%$ & $11.4 \%$ & $11.9 \%$ & $9.9 \%$ & \\
\hline & & $\geq 3$ & $1.0(-)$ & $2.63(1.55,4.46)$ & $3.05(1.75,5.30)$ & $2.54(1.33,4.87)$ & 0.001 \\
\hline \multirow{21}{*}{$\begin{array}{l}\text { Current } \\
\text { smokers }^{\ddagger}\end{array}$} & \multirow[t]{7}{*}{ 23-39 } & $n$ & 141 & 205 & 217 & 250 & \\
\hline & & 0 & $68.8 \%$ & $61.5 \%$ & $49.3 \%$ & $40.8 \%$ & \\
\hline & & 1 & $19.9 \%$ & $26.8 \%$ & $25.8 \%$ & $28.0 \%$ & \\
\hline & & 2 & $9.9 \%$ & $7.3 \%$ & $13.8 \%$ & $17.6 \%$ & \\
\hline & & 3 & $1.4 \%$ & $3.4 \%$ & $7.8 \%$ & $8.0 \%$ & \\
\hline & & $\geq 4$ & $0.0 \%$ & $1.0 \%$ & $3.2 \%$ & $5.6 \%$ & \\
\hline & & $\geq 3$ & $1.0(-)$ & $2.99(0.63,14.19)$ & $7.62(1.75,33.28)$ & $8.94(2.07,38.67)$ & $<0.001$ \\
\hline & \multirow[t]{7}{*}{$40-49$} & $n$ & 97 & 179 & 244 & 472 & \\
\hline & & 0 & $42.3 \%$ & $39.7 \%$ & $38.9 \%$ & $28.6 \%$ & \\
\hline & & 1 & $26.8 \%$ & $26.8 \%$ & $25.8 \%$ & $28.2 \%$ & \\
\hline & & 2 & $20.6 \%$ & $20.7 \%$ & $18.4 \%$ & $20.3 \%$ & \\
\hline & & 3 & $7.2 \%$ & $7.3 \%$ & $10.7 \%$ & $13.1 \%$ & \\
\hline & & $\geq 4$ & $3.1 \%$ & $5.6 \%$ & $6.1 \%$ & $9.7 \%$ & \\
\hline & & $\geq 3$ & $1.0(-)$ & $1.23(0.56,2.74)$ & $1.59(0.75,3.36)$ & $2.15(1.07,4.35)$ & 0.004 \\
\hline & \multirow[t]{7}{*}{$50-59$} & $n$ & 87 & 125 & 206 & 328 & \\
\hline & & 0 & $34.5 \%$ & $28.8 \%$ & $24.8 \%$ & $26.8 \%$ & \\
\hline & & 1 & $24.1 \%$ & $42.4 \%$ & $36.4 \%$ & $27.7 \%$ & \\
\hline & & 2 & $24.1 \%$ & $12.8 \%$ & $19.9 \%$ & $21.0 \%$ & \\
\hline & & 3 & $11.5 \%$ & $10.4 \%$ & $12.6 \%$ & $13.7 \%$ & \\
\hline & & $\geq 4$ & $5.7 \%$ & $5.6 \%$ & $6.3 \%$ & $10.7 \%$ & \\
\hline & & $\geq 3$ & $1.0(-)$ & $0.93(0.44,1.97)$ & $1.13(0.57,2.22)$ & $1.57(0.83,2.98)$ & 0.044 \\
\hline
\end{tabular}

*: Unless otherwise indicated, values are expressed as the relative risk (95\% confidence interval). ${ }^{\prime}$ Controls for age, alcohol intake, and medical treatment. $\stackrel{\ddagger}{*}$ : Additional control for cigarette smoking.

adjusted odds ratios of $\geq 3$ features of the MS compared with WBC count of $<5310^{9}$ cells/l were $1.23,1.59$, and 2.15 for those aged $40-49 \mathrm{yr}$ and $0.93,1.13$, and 1.57 for those aged $50-59 \mathrm{yr}$ ( $\mathrm{P}$ for trend $<0.001$ and $=0.044$, respectively).

\section{Discussion}

In this study, WBC count was positively associated with the components of the MS, except for HDL cholesterol 
(negative), in all three age groups of 23-39, 40-49, and 50 $59 \mathrm{yr}$. With an increase in age, however, a crude correlation between WBC count and each component of the MS declined, and an interaction with age weakened. Adjusted differences in mean WBC count for each categorized feature of the MS were the largest in the youngest age group of 23-39 yr. Stratified analyses by smoking status and age showed that in both non-smokers and current smokers adjusted differences in mean WBC count for clustered features of the MS and adjusted odds ratios of $\geq 3$ features of the MS across quartiles of WBC count were the largest in the youngest age group. Our results demonstrate that WBC count is strongly associated with a variety of features of the MS and that these tendencies are more pronounced in younger individuals in both non-smokers and current smokers.

However, the mechanism of how WBC count is associated with the features of the MS, a clinical condition that seems to be mediated by insulin resistance ${ }^{8,9)}$, is still not clear. Because insulin reduces the interleukin (IL)- 6 mediation of the acute-phase response ${ }^{30)}$, insulin resistance could lead to higher concentrations of inflammatory markers. IL-6 has been shown to be released by adipose tissue ${ }^{31)}$. Other proinflammatory cytokines such as tumor necrosis factor$\alpha$ produce insulin resistance by influencing the function of insulin receptor or impairing insulin action and inhibiting insulin secretion ${ }^{32,33)}$. Because WBC counts are increased by cytokines, especially IL- $6^{34,35)}$, and are closely associated with both insulin resistance and hyperinsulinemia ${ }^{10,11}$, the relation of WBC count with the features of the MS could be due to the presence of a subclinical inflammatory reaction and could be the expression of an insulin-resistant state or involvement of the MS.

Several studies ${ }^{14-18)}$ have examined the effect of age on the association with CHD risk factors and have documented that the relative risk for cardiovascular disease associated with these risk factors are small or negligible at higher ages. These data suggest that the impact of CHD risk factors on the risk for CHD may decrease with age. In view of the firm association of WBC count with the increased risk of $\mathrm{CHD}^{12,13)}$, our results, which showed the weaker association between WBC count and the different features of MS among older individuals, may explain the previous observations of a decrease in the estimated relative risk of CHD associated with CHD risk factors among older cohorts ${ }^{14-18)}$. Consistent with previous studies ${ }^{36-38)}$, WBC count was positively associated with cigarette smoking and negatively with alcohol intake in this population. The associations of WBC count with cigarette smoking and alcohol intake were more pronounced in individuals aged $40-59 \mathrm{yr}$ than in individuals aged 23-39 yr. This tendency was also found for medical treatment. Thus, age-related change in the strength of the association of WBC count with some features of the MS may be in part mediated by the differences in the association of WBC count with cigarette smoking, alcohol intake, and medical treatment by age. However, the cross-sectional study design lacks information on the time sequence of events and, thus, does not permit identification of causal relationships. Further studies are needed to clarify whether WBC count, although within the normal range, contributes to the development of the MS and whether there are age differences in the strength of the association of WBC count with the features of the MS.

In conclusion, our data indicate that WBC count is strongly associated with a variety of disorders characterizing the MS and that these tendencies are more pronounced in younger individuals. In consideration of the strong association between WBC count and the different features of the MS, much remains to be learned about its value as a predictor rather than merely an indicator of current infection. The stronger association observed among younger individuals also indicates that multiple clinical laboratory tests, including serum total cholesterol, HDL cholesterol, triglycerides, fasting plasma glucose, and uric acid, may be needed in terms of CHD risk assessment for young individuals with an increased WBC count.

\section{Acknowledgments}

This study was supported by grant-in-aids from the Smoking Research Foundation, Tokyo, Japan and the prevention of lifestyle-related diseases from the Arteriosclerosis Prevention Association, Tokyo, Japan.

\section{References}

1) Vallance P, Collier J, Bhagat K (1997) Infection, inflammation, and infarction: does acute endothelial dysfunction provide a link? Lancet 349, 1391-2.

2) Hingorani $A D$, Cross J, Kharbanda RK, Mullen MJ, Bhagat K, Taylor M, Donald AE, Palacios M, Griffin GE, Deanfield JE, MacAllister RJ, Vallance P (2000) Acute systemic inflammation impairs endotheliumdependent dilatation in humans. Circulation 102, 9949.

3) Sinisalo J, Paronen J, Mattila KJ, Syrjala M, Alfthan G, Palosuo T, Nieminen MS, Vaarala O (2000) Relation of inflammation to vascular function in patients with coronary heart disease. Atherosclerosis 149, 403-11. 
4) Babior BM (2000) Phagocytes and oxidative stress. Am J Med 109, 33-44.

5) Lipowsky HH, Usami S, Chien S (1980) In vivo measurements of "apparent viscosity" and microvessel hematocrit in the mesentery of the cat. Microvasc Res 19, 297-319.

6) Harlan JM (1985) Leukocyte-endothelial interactions. Blood 65, 513-25.

7) Ito BR, Schmid-Schönbein G, Engler RL (1990) Effects of leukocyte activation on myocardial vascular resistance. Blood Cells 16, 145-63.

8) Ferrannini E, Haffner SM, Mitchell BD, Stern MP (1991) Hyperinsulinaemia: the key feature of a cardiovascular and metabolic syndrome. Diabetologia 34, 416-22.

9) DeFronzo RA, Ferrannini E (1991) Insulin resistance. A multifaceted syndrome responsible for NIDDM, obesity, hypertension, dyslipidemia, and atherosclerotic cardiovascular disease. Diabetes Care 14, 173-94.

10) Targher G, Seidell JC, Tonoli M, Muggeo M, De Sandre G, Cigolini M (1996) The white blood cell count: its relationship to plasma insulin and other cardiovascular risk factors in healthy male individuals. J Intern Med 239, 435-41.

11) Vozarova B, Weyer C, Lindsay RS, Pratley RE, Bogardus C, Tataranni PA (2002) High white blood cell count is associated with a worsening of insulin sensitivity and predicts the development of type 2 diabetes. Diabetes 51, 455-61.

12) Weijenberg MP, Feskens EJ, Kromhout D (1996) White blood cell count and the risk of coronary heart disease and all-cause mortality in elderly men. Arterioscler Thromb Vasc Biol 16, 499-503.

13) Sabatine MS, Morrow DA, Cannon CP, Murphy SA, Demopoulos LA, DiBattiste PM, McCabe CH, Braunwald E, Gibson CM (2002) Relationship between baseline white blood cell count and degree of coronary artery disease and mortality in patients with acute coronary syndromes: a TACTICS-TIMI 18 substudy. J Am Coll Cardiol 40, 1761-8.

14) Stevens J, Cai J, Pamuk ER, Williamson DF, Thun MJ, Wood JL (1998) The effect of age on the association between body-mass index and mortality. N Engl J Med 338, $1-7$.

15) Langer RD, Ganiats TG, Barrett-Connor E (1989) Paradoxical survival of elderly men with high blood pressure. BMJ 298, 1356-7.

16) Manolio TA, Pearson TA, Wenger NK, Barrett-Connor E, Payne GH, Harlan WR (1992) Cholesterol and heart disease in older persons and women. Review of an NHLBI workshop. Ann Epidemiol 2, 161-76.

17) Whisnant JP, Wiebers DO, O'Fallon WM, Sicks JD, Frye RL (1996) A population-based model of risk factors for ischemic stroke: Rochester, Minnesota. Neurology 47, 1420-8.

18) Howard G, Manolio TA, Burke GL, Wolfson SK, O'Leary DH (1997) Does the association of risk factors and atherosclerosis change with age? An analysis of the combined ARIC and CHS cohorts. The Atherosclerosis Risk in Communities (ARIC) and Cardiovascular Health Study (CHS) investigators. Stroke 28, 1693-701.

19) McNamara JJ, Molot MA, Stremple JF, Cutting RT (1971) Coronary artery disease in combat casualties in Vietnam. JAMA 216, 1185-7.

20) Zieske AW, Malcom GT, Strong JP (2002) Natural history and risk factors of atherosclerosis in children and youth: the PDAY study. Pediatr Pathol Mol Med 21, 213-37.

21) Hansen LK, Grimm RH Jr, Neaton JD (1990) The relationship of white blood cell count to other cardiovascular risk factors. Int J Epidemiol 19, 881-8.

22) Friedman GD, Tekawa I, Grimm RH, Manolio T, Shannon SG, Sidney S (1990) The leucocyte count: correlates and relationship to coronary risk factors: the CARDIA study. Int J Epidemiol 19, 889-93.

23) Nieto FJ, Szklo M, Folsom AR, Rock R, Mercuri M (1992) Leukocyte count correlates in middle-aged adults: the Atherosclerosis Risk in Communities (ARIC) Study. Am J Epidemiol 136, 525-37.

24) Zeltser D, Rogowski O, Fusman R, Rotstein R, Rubinstein A, Koffler M, Shibolet S, Berliner S, Shapira I (2001) The multiplicity of atherosclerotic risk factors corresponds to the appearance of increased leukocyte count in the peripheral blood: relevance to the pathogenesis of the disease. J Cardiovasc Risk 8, 37982.

25) Nakanishi N, Sato M, Shirai K, Nakajima K, Murakami S, Takatorige T, Suzuki K, Tatara K (2002) Associations between white blood cell count and features of the metabolic syndrome in Japanese male office workers. Ind Health 40, 273-7.

26) World Hypertension League (1989) Weight control in the management of hypertension. Bull World Health Organ 67, 245-52.

27) World Health Organization Expert Committee (1978) Arterial hypertension. Report of a WHO expert committee. World Health Organ Tech Rep Ser 628, 7-56. 
28) Investigating Committee of Guideline for Diagnosis and Treatment of Hyperlipidemia, Japan Atherosclerosis Society (1997) Guideline for Diagnosis and Treatment of Hyperlipidemia in Adults. J Atherosclerosis Soc 25, $1-34$.

29) The Expert Committee on the Diagnosis and Classification of Diabetes Mellitus (1997) Report of the Expert Committee on the Diagnosis and Classification of Diabetes Mellitus. Diabetes Care 20, 1183-97.

30) Campos SP, Baumann H (1992) Insulin is a prominent modulator of the cytokine-stimulated expression of acute-phase plasma protein genes. Mol Cell Biol 12, 1789-97.

31) Mohamed-Ali V, Goodrick S, Rawesh A, Katz DR, Miles JM, Yudkin JS, Klein S, Coppack SW (1997) Subcutaneous adipose tissue releases interleukin-6, but not tumor necrosis factor-alpha, in vivo. J Clin Endocrinol Metab 82, 4196-200.

32) Uysal KT, Wiesbrock SM, Marino MW, Hotamisligil GS (1997) Protection from obesity-induced insulin resistance in mice lacking TNF- $\alpha$ function. Nature 389,
$610-4$.

33) Hotamisligil GS, Peraldi P, Budavari A, Ellis R, White MF, Spiegelman BM (1996) IRS-1-mediated inhibition of insulin receptor tyrosine kinase activity in TNF-alphaand obesity-induced insulin resistance. Science 271, 665-8.

34) Sim E (1993) Humoral factors. IRL Press, Oxford.

35) Memon RA, Feingold KR, Grunfeld C (1997) Cytokines and intermediary metabolism. In: Cytokines in health and disease. 2nd ed. eds. by Remick DG, Friedland JS, 381-99, Marcel Dekker, New York.

36) Corre F, Lellouch J, Schwartz D (1971) Smoking and leucocyte-counts. Results of an epidemiological survey. Lancet 2, 632-4.

37) Friedman GD, Siegelaub AB, Seltzer CC, Feldman R, Collen MF (1973) Smoking habits and the leukocyte count. Arch Environ Health 26, 137-43.

38) Nakanishi N, Yoshida H, Okamoto M, Matsuo Y, Suzuki K, Tatara K (2003) Association of alcohol consumption with white blood cell count: a study of Japanese male office workers. J Intern Med 253, 367-74. 